\title{
COMPARISON BETWEEN BRAZIL AND CANADA AS REGARDS COMPETITIVENESS IN CONIFEROUS SAWN TIMBER PRODUCTION
}

\author{
Alexandre Nascimento de Almeida ${ }^{1 *}$, João Carlos Garzel Leodoro da Silva² ${ }^{2}$ Humberto Angelo $^{1}$ \\ *Corresponding author: alexfloresta@pop.com.br
}

\begin{abstract}
The objective of this study is to identify strengths and weaknesses of Brazil and Canada regarding the production of coniferous sawn timber, based on an opinion survey with entrepreneurs operating in that business segment. The method selected for use was cluster analysis and results led to the conclusion that Brazil's main strengths relate to the expansion potential of its domestic and export markets and also to the high productivity and profitability of its forests, while, as for Canada, in addition to having an extensive area with commercial forests, a major strength is the commitment of the Canadian government to provide adequate infrastructure for the sawn timber industry to operate effectively.
\end{abstract}

Key words: Cluster analysis, opinion survey, benchmarking.

\section{COMPARAÇÃO ENTRE A COMPETITIVIDADE DO BRASIL E CANADÁ PARA A PRODUÇÃO DE MADEIRA SERRADA DE CONÍFERAS}

RESUMO: Neste trabalho, objetivou-se identificar os pontos fortes e fracos do Brasil e Canadá para a produção de madeira serrada de coniferas, a partir da opinião dos empresários do segmento. O método aplicado é a analise de cluster e os resultados ensejaram as seguintes conclusões: os principais pontos fortes do Brasil referem-se ao potencial de expansão do mercado interno e das exportações, bem como à alta produtividade e rentabilidade das florestas; além da extensa área de florestas comerciais no Canadá, destacou-se o comprometimento do governo canadense no provimento de uma infraestrutura adequada para atuação do seu segmento de serrados.

Palavras-chave: Análise de cluster, pesquisa de opinião, benchmarking.

\section{INTRODUCTION}

In 2011, the international market of coniferous sawn timber traded US $\$ 23$ billion, with Brazil contributing less than $1 \%$ of this total, despite the high productivity of its pine forests, which means it has yet considerable untapped potential for growth (FOOD AND AGRICULTURE ORGANIZATION OF THE UNITED NATIONS - FAO, 2012). Growth entails being competitive not only with regard to boosting forest productivity but also with regard to processing and trading the resulting timber, a current challenge facing Brazil in the world market.

The primary function of studies about competitiveness is to allow comparison with world-class standards so as to identify competitive advantages and disadvantages and to help improve policy measures and production practices.

According to FAO (2012), in recent decades, Canada has been the world's largest exporter of sawn timber, demonstrating its international competitiveness and benchmarking comparison with competitor Brazil.

The increasing, inevitable globalization of world economies has opened up opportunities but has also brought threats. Where companies are competitive, not only do they secure the domestic market against competitors but they will also extend their profits to the foreign market, or else their inevitable fate is to dwindle to a point where they will disappear, affecting the vigor of society as a whole.

The objective of this study is to analyze the business environment for sawn timber production in Brazil and in Canada, highlighting the strengths and weaknesses of each country, according to the opinion of entrepreneurs in each respective country.

\section{MATERIAL AND METHODS}

\subsection{Theoretical framework}

Although seemingly trivial, competitiveness is yet a virtually undefined concept (KUPFER, 1991). Haguenauer (1989) organized the various notions of competitiveness into two groups:

1) Competitiveness as Performance - This concept assesses competitiveness based on the effects it has on the foreign market. It is also a broader concept of competitiveness, encompassing not only production

${ }^{1}$ Universidade de Brasília - Planaltina, Distrito Federal, Brazil

${ }^{2}$ Universidade Federal do Paraná - Curitiba, Paraná, Brazil

Cerne, Lavras, v. 19, n. 3, p. 415-421, jul./set. 2013 
conditions but also all factors potentially inhibiting or boosting the exports of specific products and/or countries, as for instance, exchange rate and trade policies, efficiency of trade channels and financing systems, international agreements between countries or companies, strategies of transnational firms, etc.

2) Competitiveness as Efficiency -Another school of authors view competitiveness as a structural feature, conceptualizing it as the capability of a country to produce certain goods so as to match or surpass efficiency levels observed in other economies. Growth in exports is viewed as a possible consequence rather than as an expression of competitiveness.

\subsection{Analytical framework}

The methodological approach was based on the concept of competitiveness as efficiency and analyzed 24 variables composing seven categories which are typically used for measuring competitiveness: 1) Structural factors (FE); 2) Technology (TE); 3) Management systems (SG); 4) Market (ME); 5) Related and supporting industries (IRA); 6) Government and public sector policies (PGP); 7) Company strategies (EC) (Table 1). The selection of variables was influenced by the Global Competitiveness Index as provided by the World Economic Forum (WORLD ECONOMIC FORUM - WEF, 2010).

The analysis of the above variables was based on responses to a questionnaire by high ranked people in sawn timber companies of both Brazil and Canada. The entrepreneurs of both countries were asked to issue their opinion on the current situation of each variable of interest using a semantic differential scale.

A semantic differential scale connects two opposing alternatives or statements (one favorable and one unfavorable to competitiveness in this case) on a sevenpoint itemized scale. In order to facilitate discussion of results, the points in the scale are defined as having the following attributes: 1) extremely unfavorable (ed); 2) very unfavorable (md); 3) unfavorable (d); 4) indifferent (i); 5) favorable (f); 6) very favorable (mf); and 7) extremely favorable (ef).

For data analysis, cluster dendrograms were used. Cluster analysis is a multivariate method for detecting homogeneous groups of variables using measures of similarity. The Euclidean distance was adopted as a measure of similarity and the Ward's procedure was used for connecting clusters, the most commonly used measure and procedure respectively (HAIR JUNIOR et al., 2005).
Table 1 - Variables of interest and respective categories.

Tabela 1 - Variáveis analisadas e respectivas categorias.

\begin{tabular}{|c|c|c|}
\hline Categ. & $\begin{array}{l}\text { Variable } \\
\text { Acronym }\end{array}$ & Variable \\
\hline \multirow{3}{*}{$\mathrm{FE}$} & $\mathrm{DM}$ & Timber availability \\
\hline & IMO & Influence of labor \\
\hline & IEP & Public infrastructure \\
\hline \multirow{3}{*}{$\mathrm{TE}$} & IET & Technology infrastructure \\
\hline & ETEC & Company's technological effort \\
\hline & $\mathrm{RP}$ & Patent registration \\
\hline \multirow{2}{*}{ SG } & IEA & Management infrastructure \\
\hline & EGC & Company's managerial effort \\
\hline \multirow{6}{*}{ ME } & MMD & Domestic market maturity \\
\hline & CCD & Domestic consumer awareness \\
\hline & $\mathrm{BC}$ & Presence of trade barriers \\
\hline & DMF & Financial market development \\
\hline & MME & Machinery and equipment market \\
\hline & EMC & Company's market effort \\
\hline \multirow{2}{*}{ IRA } & EIC & Individual company effort \\
\hline & $\mathrm{ECC}$ & Collective company effort \\
\hline \multirow{6}{*}{ PGP } & AGC & Government support \\
\hline & $\mathrm{AL}$ & Legal aspects \\
\hline & PCI & International trade policy \\
\hline & PCIn & Internal competitiveness policy \\
\hline & $\operatorname{IPr}$ & Private investment in forests \\
\hline & PQ & $\begin{array}{l}\text { Quality standard requirement in } \\
\text { the domestic market }\end{array}$ \\
\hline \multirow{2}{*}{$\mathrm{EC}$} & $\mathrm{HE}$ & Strategic horizon \\
\hline & EEC & Company's strategic effort \\
\hline
\end{tabular}

The reason for choosing the Ward's method was that it tends to combine aggregations with a small number of variables and to produce clusters with roughly the same number of observations, facilitating interpretation.

The aim of using cluster analysis was to observe the grouping of variables according to the defined attributes, allowing an exploratory analysis of the strengths and weaknesses of Brazil and Canada based on the 24 variables of interest. The analysis sought to differentiate between three groups:

1. Strong points: variables tending to cluster around attributes favorable to competitiveness ('f', 'mf' and 'ef').

Cerne, Lavras, v. 19, n. 3, p. 415-421, jul./set. 2013 
2. Weak points: variables tending to cluster around attributes unfavorable to competitiveness (' $d$ ', 'md' and 'ef').

3. Indifferent points: variables tending to cluster around indifferent points (' $i$ ').

\subsection{Data base}

The universe of this research comprised companies trading coniferous sawn timber among their product mix. The relevant data was collected between January and July 2008 and resulted in 66 questionnaires answered in Brazil and 40 questionnaires answered in Canada, accounting for around 3\% and 10\% of Brazil's (South and Southeast) and Canada's total population of sawn timber companies respectively (INSTITUTO BRASILEIRO DE GEOGRAFIA E ESTATÍSTICA - IBGE, 2010; SPELTER; ALDERMAN, 2005).

\section{RESULTS AND DISCUSSION}

The cluster analysis helped differentiate extremes (strengths and weaknesses) from indifferent variables with a Euclidean distance of three units for Brazil and Canada (Figure 1).

Other than the variables related to forestry itself, which favor wide timber availability, other strengths worthy of mention in support of the Brazilian sawn timber environment are internal demand potential and items favoring international trade.

Some variables identified as strengths by Brazilian entrepreneurs relate to aspects that, typically, are found in worse conditions in developing countries but that nonetheless were either not regarded as constraints or have even reached an acceptable level in Brazil, and include machinery and equipment market, legal aspects and financial market development.

Other variables viewed as supportive to Brazil's competitiveness relate to strategic issues and to quality standard requirements for sawn timber. For these variables, no theoretical justification was found to corroborate the favorable perception on the part of entrepreneurs. Other strengths cited were found to meet expectations.

The issue concerning application of a consistent strategy led to dubious interpretations by respondents. On the one hand, they signaled having a consistent strategy and yet on the other hand they pointed to shortcomings in the managerial structure and in company relationships along the production chain. Typically, the development of a consistent strategy is conditional on a well planned managerial structure and on robust relationships with support companies.

Results found by Simione (2007) corroborate the absence of an associative culture in Brazil's timber production chain, which may be a limiting factor for establishment of a consistent strategy. The author also reported that the low levels of schooling found by collaborators in the timber industry again is a limiting factor affecting the management of company processes, pointing out that lack of knowledge obstructs the implementation of technological and organizational innovations within companies.

Consequently, given the absence of an associative culture among sawn timber companies, and also managerial constraints, the strength reported by Brazilian entrepreneurs regarding strategy is seemingly illegitimate. In that regard, one should note the difficulty of interviewees in judging their own performance, hence the need for careful assessment of these results.

The requirement for high quality standards by Brazilian and Canadian governments as regards manufacture of sawn timber products is a strong point for competitiveness, noting that this requirement for quality in the domestic market does prepare companies to compete with world-class standards both home and abroad, although, as with strategy, this claim is seemingly illegitimate in the case of Brazil.

One weakness identified by Brazilian sawn timber entrepreneurs was that Brazilian consumers are not willing to pay for quality (domestic consumer awareness - CCD). Judging by Brazil's low levels of per capita income and schooling, the perception of Brazilian entrepreneurs regarding $\mathrm{CCD}$ does seem realistic, yet the perception that the government imposes strict quality standards (PQ) without backup from domestic consumers (CCD) is arguable.

The weaknesses described by Brazilian entrepreneurs were in line with expectations and related to the incapability of the State to establish a suitable infrastructure, particularly in regard to managerial and technological aspects, or to provide companies with direct support through incentives and subsidies.

Infrastructure problems reported by Brazilian entrepreneurs echoed the clamor of the national business sector for a remedy in that regard, reflected by continual use of the expression 'Brazil cost' (referring to increased operational costs associated with doing business in Brazil) as a justification for the lack of Brazilian competitiveness.

Cerne, Lavras, v. 19, n. 3, p. 415-421, jul./set. 2013 

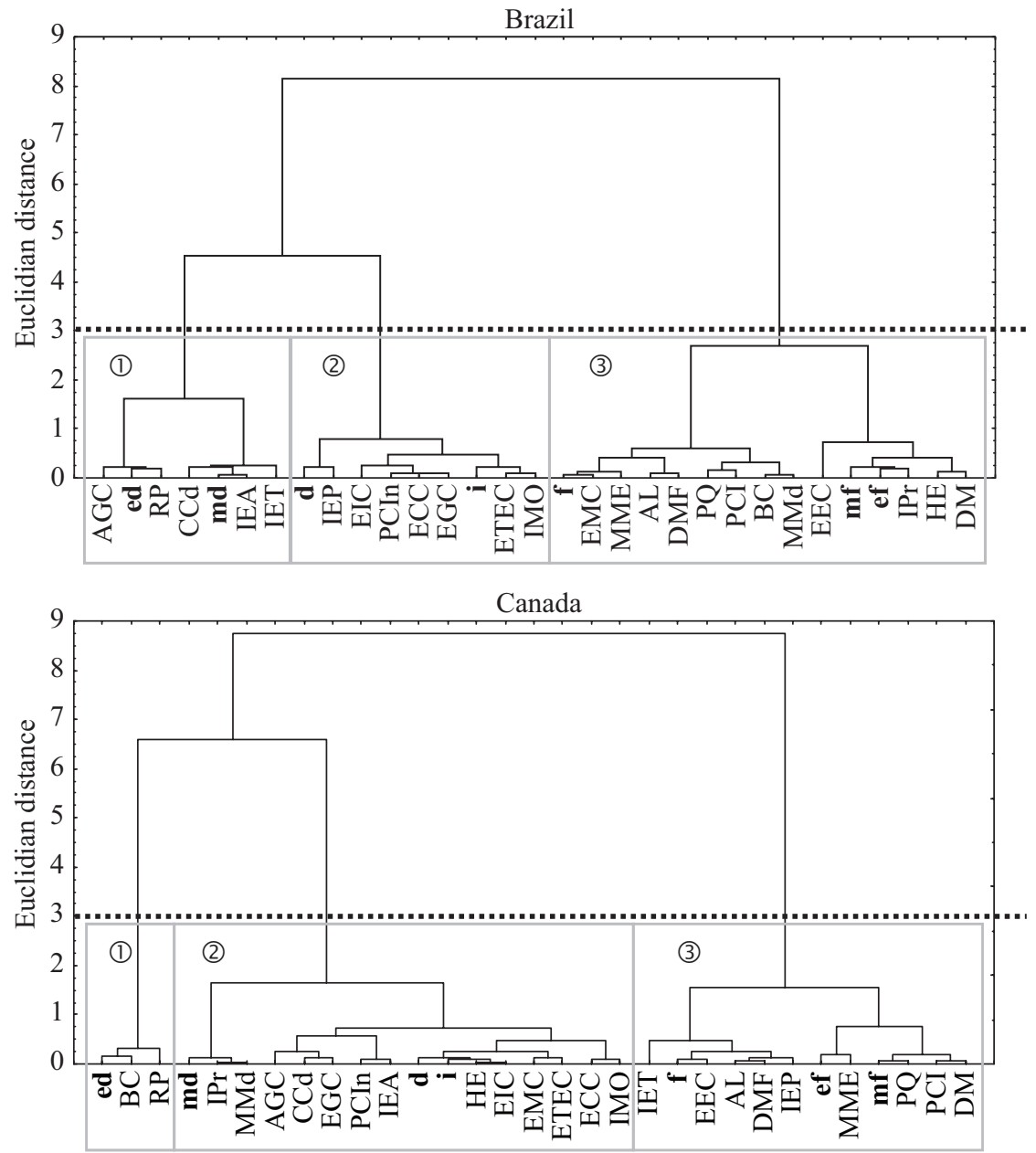

${ }^{\circledR}$ Weak points; ${ }^{\circledR}$ indifferent points; ${ }^{\circledR}$ strong points; AL legal aspects; RP patent registration; CCD domestic consumer awareness; IEA management infrastructure; IET technology infrastructure; IEP public infrastructure; EIC individual company effort; PCIn internal competitiveness policy; ECC collective company effort; EGC company's managerial effort; ETEC company's technological effort; IMO influence of labor; EMC company's market effort; MME machinery and equipment market; AGC government support; DMF financial market development; PQ quality standard requirement; PCI international trade policy; BC presence of trade barriers; MMD domestic market maturity; EEC company's strategic effort; IPr private investment in forests; HE strategic horizon; DM timber availability; ed extremely unfavorable; md very unfavorable; $d$ unfavorable; i indifferent; f favorable; mf very favorable; and ef extremely favorable.

${ }^{\oplus}$ Pontos fracos; ${ }^{\circledR}$ pontos indiferentes; ${ }^{\circledR}$ pontos fortes; AL aspectos legislativos; RP registro de patentes; CCd consciência do consumidor doméstico; IEA infraestrutura para administração; IET infraestrutura para tecnologia; IEP infraestrutura pública; EIC esforço individual das companhias; PCIn política de competição interna; ECC esforço coletivo das companhias; EGC esforço gerencial das companhias; ETEC esforço tecnológico empregado pelas companhias; IMO influência de mão de obra; EMC esforço de mercado pelas companhias; MME mercado de máquinas e equipamentos; AGC apoio governamental para as companhias; $D M F$ desenvolvimento do mercado financeiro; $P Q$ exigência de padrão de qualidade; PCI política de comércio internacional; $B C$ presença de barreiras comerciais; MMd maturidade do mercado doméstico; EEC esforço estratégico das companhias; IPr investimento privado em floresta; HE horizonte estratégico; DM disponibilidade de madeira; ed extremamente desfavorável; md muito desfavorável; d desfavorável; i Indiferente; ffavorável; mf muito favorável; e ef extremamente favorável.

Figure 1 - Cluster analysis for Brazil and Canada.

Figura 1 - Análise de cluster para o Brasil e o Canadá.

Cerne, Lavras, v. 19, n. 3, p. 415-421, jul./set. 2013 
As regards providing companies with direct support, criticism was seemingly fair, since other sectors of the Brazilian economy are given better treatment. For instance, credit loans with interest rates subsidized by BNDES (national bank for economic and social development) via TJLP (long term interest rate) are directed according to government decisions. And, according to Almeida (2006), the timber industry is, by a long way, not receiving the same treatment as other sectors of the Brazilian industry regarding these public fundings.

Additionally, just as with the paper and pulp sector, the mechanical processing sector has great competitive advantages due to the high productivity of the Brazilian forests, yet it has not received the same support for advancement over time. Some government fundings regarded as critical to the pulp and paper sector included the tax incentive bill (LIF) and two nationwide pulp and paper programs (PNPC), in 1974 and 1987, although nothing of the sort happened to the sawn timber sector. More recently, however, a reduction has been approved in the tax on industrialized products (IPI) for furniture items, indirectly benefiting the sawn timber sector, though timidly.

As regards patent registration in the timber sector, the practice was described as rare by entrepreneurs of Brazil and Canada. With the timber sector being one of low technological intensity, this aspect was not thought to be a weakness in either of the two business environments, but rather it was viewed as an unrealistic variable for the sawn timber sector worldwide, though widely used in studies about competitiveness as an indicator of technological development.

Overall, the strengths reported by Canadian entrepreneurs were also in line with expectations and relate to indirect, adequate influence of the developmentinducing State, and to issues inherent in developed countries (robust legislation, development of both the financial and the machinery \& equipment markets, liberal international trade policy), and to characteristics peculiar to the Canadian forestry sector.

Both Brazilian and Canadian entrepreneurs pointed to forestry as being a strong point of their business environment. In the case of Brazil, this result is explained by the high productivity of the country's nonnative forests, while in the case of Canada the justification is the country's extensive forest cover as well as ample infrastructure for logging activities.

Among the world's leading producers of forest products, Brazil has the most productive forests. According to the Brazilian association of nonnative forest producers
Associação Brasileira de Produtores de Florestas Plantadas ABRAF (2010), the average productivity of Brazil's nonnative forests is roughly $30 \mathrm{~m}^{3} /$ hectare/year, six times higher than Canada's $5 \mathrm{~m}^{3} /$ hectare/year. Canada, in turn, boasts the world's third largest forest cover (300 million hectares), only behind Russia (809 million hectares) and Brazil (478 million hectares) (FAO, 2012).

In contrast with Canada, Brazil's extensive forest cover owes mainly to the Amazon region, which has not been explored accordingly by the timber industry because of legal and environmental issues, lack of infrastructure, among other reasons. In 2005, the nonnative forest cover in Brazil was only 6 million hectares, far behind the area covered with commercial forests in Canada, around 235 million hectares (FAO, 2012; FLORESTAS..., 2002).

Both Brazil and Canada have advantages in terms of timber availability, yet the source of advantage differs widely. In Brazil, forestry activity is more profitable mainly due to high productivity and low cost of land, which naturally attract many foreign investments (TUOTO, 2007). In Canada, the State strongly influences the timber supply whereas private investments are either scarce or nonexistent.

But lack of private investment is not an impediment to timber availability in Canada, given the extensive forest cover that is held in government possession. While a government-controlled supply can benefit the local business environment through oversupply and consequently low timber prices, it can also not only inhibit private investments in timber production and thus prevent the emergence of a more efficient market, but it can also spark trade retaliations by competitors, especially the U.S.

The weakness described by Canadian entrepreneurs regarding presence of trade barriers reflects a troubled relationship with the U.S. in sawn timber trade (YIN; BAEK, 2004). Though Canada has been gradually diversifying its trade partners, with the U.S. accounting for $64 \%$ of its internationally traded sawn timber in 2009 (UNCOMTRADE, 2010), the volume exported by Canada, plus the concentration in one single country, United States, naturally leads to the emergence of trade barriers difficult to overcome.

As regards the variable international trade policy, identified as strength for both countries, it was understood that a policy in support of a free market is conducive to competitiveness, yet remembering that protectionist measures for emerging industry segments should be observed, though not the case with the sawn timber sector in Brazil or Canada.

Cerne, Lavras, v. 19, n. 3, p. 415-421, jul./set. 2013 
A free market policy involves considerations of tax-related barriers as well as other barriers, the latter more difficult to quantify. Overall, the import tax applied by Brazilian authorities on timber products is low if compared to other Brazilian industry sectors, ranging from $2 \%$ for low value-added products such as logged wood and charcoal, to $6 \%$ for sawn timber, $10 \%$ for panels, and $14 \%$ for high value-added products such as doors and windows. Brazil's most protected industry sectors include several products in the textile, shoes and automobile industry, as they are taxed the maximum rate allowed by the WTO which is $35 \%$ (BRASIL, 2010).

Comparatively to Canada, the import taxes applied in Brazil on timber products are high. Many timber products are not taxed in Canada and those taxed are subjected to an average tax rate of $6 \%$. Sawn timber and MDF, for instance, are not taxed, while laminates, windows and picture frames are taxed $6 \%$, plywood is taxed $5 \%$, flooring is taxed $3.5 \%$, OSB and particleboard are taxed $2.5 \%$ (CANADA BORDER SERVICES AGENCY CBSA, 2010).

These import taxes presented for Brazil and Canada do not apply to trade partners as, naturally, business between trade partners is taxed less or nothing at all. Canada's main trade partners, for instance, are United States, Mexico, Chile, Costa Rica, Israel, Australia, New Zealand, Norway, Iceland, Switzerland, Peru and Jordan. These countries are subjected to zero tax on all previously mentioned timber products. Likewise, trade within the MERCOSUL between Brazil, Argentina, Uruguay and Paraguay is also subjected to special taxation.

Given the larger number of trade partners with bilateral or multilateral agreements and the lower import taxes on timber products occurring in Canada, it can be said that Canada's international trade policy is more liberal than Brazil's for timber products, noting that, since the 1990s Brazil has opened its economy and has evolved in this respect, which means this is not a limiting factor for the development of its sawn timber sector.

As was expected, a strong point defined by Canadian entrepreneurs concerns the machinery and equipment market. Not only is Canada a developed country having more favorable structural conditions for establishment of a high value-added industry such as machinery and equipment, but it is also favorably located, lying next to the world's largest industrial power, United States. Surely, both of these factors facilitate acquisition of suitable machinery and equipment by Canadian entrepreneurs.

Cerne, Lavras, v. 19, n. 3, p. 415-421, jul./set. 2013
Brazilian entrepreneurs reported no major constraints on the variable machinery and equipment market, perhaps influenced by the continual expansion of the Brazilian market since the 1990s, which facilitated acquisition of imported machinery and equipment, or by the adaptation of production processes using obsolete machinery, that way minimizing the importance of this market, according to their perception.

That does not mean that Brazilian sawmills boast modern machinery. Simioni (2007) identified a pressing need for renewal of machinery and equipment in sawmills of southern Brazil in order to cope with current market conditions. According to the author, the required renewal index reported by sawmills in Lages (SC) can be as high as $90 \%$ in some cases.

Technological development in Canadian and Brazilian timber companies differs considerably. Rocha (2002) compiled a list of sawmill efficiency ratings in some regions of the world and found that while most nonnative timber sawmills in Brazil reach an efficiency of 5 to $10 \mathrm{~m}^{3 /}$ worker/day, in developed countries they reach more than $50 \mathrm{~m}^{3} /$ worker/day, and that includes Canada.

Another strong point for the Canadian business environment concerns the legal assurance resulting from adequacy, stability, agility and application of the relevant environmental and forest legislation and of forest management. As in any other developed country, these results met expectations, as Canada is in an advanced democratic stage.

For Brazilian entrepreneurs, the justification for not having detected shortcomings in the environmental and forest legislation or forest management is due to the relatively few restrictions imposed on nonnative forest logging in Brazil and to the fact that, overall, entrepreneurs lack their own reforested crops and thus miss the official forms and procedures involving forestry activities.

\section{CONCLUSIONS}

Brazil's main strengths related to the expansion potential of both its domestic and export markets and also to the high productivity and profitability of the local forests, increasingly attracting private investments in the sector and allowing a more efficient and environmentally acceptable timber production.

Brazil's weaknesses related to an inefficient infrastructure and inadequate support to timber companies through incentives and subsidies. 
Similarly to Brazil, Canada's forestry sector has many strong points supporting wide timber availability. Canada's main advantages related to variables inherent in government commitment to the development of the entire nation, much like a development-inducing State, that way securing suitable conditions for the development of the sawn timber sector as well.

Canada's main weakness resulted from it being highly dependant on the external market, combined with poor diversification of its exports, which make Canada highly dependent on the U.S. market.

\section{REFERENCES}

ALMEIDA, A. N. Estudo econométrico da demanda e oferta de madeira em tora para o processamento mecânico no Estado do Paraná. 2006. 217 f. Dissertação (Mestrado em Ciências Florestais) - Universidade Federal do Paraná, Curitiba, 2006.

ASSOCIAÇÃO BRASILEIRA DE PRODUTORES DE FLORESTAS PLANTADAS. Anuário estatístico, 2005, 2006, 2007 e 2008. Disponível em: $<$ http://www.abraflor.org .br/estatisticas.asp>. Acesso em: 7 nov. 2010.

BRASIL. Ministério do Desenvolvimento Indústria e Comércio Exterior. Comércio exterior: histórico. Disponível em: <http://www.desenvolvimento.gov.br/sitio/interna/interna. php?area $=5 \&$ menu $=1848>$. Acesso em: 7 nov. 2010.

\section{CANADA BORDER SERVICES AGENCY. Tariff}

classification. Disponível em: <http://www.cbsa.gc.ca/>. Acesso em: 7 nov. 2010.

FLORESTAS canadenses: um vasto e complexo recurso. Revista da Madeira, São Paulo, n. 66, ago. 2002. Disponível em: $<$ http://www.remade.com.br/br/revistadamadeira_materia. php?num $=197 \&$ subject $=$ Canadá $\&$ title $=$ Florestas canadensesum vasto e complexo recurso $>$. Acesso em: 10 dez. 2011.

FOOD AND AGRICULTURE ORGANIZATION OF THE UNITED NATIONS. Estatísticas florestais. Disponível em: $<$ http://faostat.fao.org/site/291/default.aspx>. Acesso em: 13 out. 2012.
HAGUENAUER, L. Competitividade: conceitos e medidas, uma resenha da bibliografia recente com ênfase no caso brasileiro. Rio de Janeiro: UFRJ/IEI, 1989. (Texto para Discussão, 211).

HAIR JUNIOR, J. F.; ANDERSON, R. E.; TATHAM, R. L.; BLACK, W. C. Análise multivariada de dados. 5. ed. Porto Alegre: Bookman, 2005. 593 p.

\section{INSTITUTO BRASILEIRO DE GEOGRAFIA E}

ESTATÍSTICA. Anuário estatístico brasileiro. Disponível: <http://www.ibge.gov.br/home/>. Acesso em: 7 nov. 2010.

KUPFER, D. Padrões de concorrência e competitividade. Rio de Janeiro: IEI/UFRJ, 1991. (Texto para Discussão, 265).

ROCHA, M. P. da. Técnicas de planejamento em serrarias. Curitiba: FUPEF, 2002. 121 p. (Série Didática FUPEF, 02/01).

SIMIONI, F. J. Análise diagnóstica e prospectiva da cadeia produtiva de energia de biomassa de origem florestal no planalto sul de Santa Catarina. 2007. $131 \mathrm{f}$. Tese (Doutorado em Ciências Florestais) - Universidade Federal do Paraná, Curitiba, 2007.

SPELTER, H.; ALDERMAN, M. Profile 2005: softwood sawmills in the United States and Canada. Madison: USDA, 2005. (Research Paper FPL-RP-630).

TUOTO, M. A. M. Os investimentos estrangeiros diretos no Brasil: um estudo de caso do setor florestal. 2007. $121 \mathrm{f}$. Dissertação (Mestrado em Ciências Florestais) - Universidade Federal do Paraná, Curitiba, 2007.

UNCOMTRADE. United Nations commodity trade statistics database. Disponível em: $<$ http://comtrade.un.org/ db/default.aspx $>$. Acesso em: 7 nov. 2010.

\section{WORLD ECONOMIC FORUM. Global Competitiveness}

Report. Disponível em: $<$ http://www.weforum.org/en/index. htm>. Acesso em: 7 nov. 2010.

YIN, R.; BAEK, J. The US-Canada softwood lumber trade dispute: what we know and what we need to know. Forest Policy and Economics, London, v. 6, p. 129-143, 2004.

Received: May 19, 2011; accepted: January 25, 2013.

Cerne, Lavras, v. 19, n. 3, p. 415-421, jul./set. 2013 
